\title{
FASILITAS ASRAMA DAN BELAJAR MAHASISWA UNIVERSITAS TARUMANAGARA
}

\author{
Raphael Gusanto ${ }^{1)}$, Suwardana Winata ${ }^{2)}$ \\ 1)Program Studi S1 Arsitektur, Fakultas Teknik, Universitas Tarumangara, raph.gusanto@gmail.com \\ 2) Program Studi S1 Arsitektur, Fakultas Teknik, Universitas Tarumanagara, danarsitek@gmail.com
}

\begin{abstract}
Abstrak
Millennial atau Generasi Y, dikenal sebagai generasi dengan jumlah terbesar. Terbentuk di tengah dua fenomena besar, yakni teknologi dan terorisme telah membentuk sejumlah karakteristik baru. Karakteristik inilah yang akhirnya mempengaruhi cara mereka hidup dan tinggal, bahkan merespon suatu objek arsitektur. Millennial memilih untuk tinggal di kota besar, meskipun harga kepemilikan rumah cenderung mahal. Hal ini memicu urbanisasi yang disebabkan oleh tingkat pendidikan lebih tinggi di kota. Jakarta sebagai ibukota negara merupakan salah satu kota dengan penduduk terbesar di Indonesia dengan biaya hidup yang mahal. Setiap tahunnya, terjadi urbanisasi mahasiswa yang mengejar pembelajaran di Universitas Tarumanagara, baik secara commuter maupun musiman. Namun dikarenakan keterbatasan lahan dan kepadatan penduduk membuat hunian mahasiswa menjadi tidak efisien. Baik dari segi jarak, waktu, maupun energi untuk mencapai tempat pembelajaran dan melakukan kegiatan sehari-hari. Untuk itu diperlukannya hunian bagi mahasiswa yang efisien dan dapat menunjang pembelajarannya, berbentuk fasilitas asrama dan belajar Universitas Tarumanagara.
\end{abstract}

Kata kunci: Asrama; Hunian; Millennial; Universitas Tarumanagara

\begin{abstract}
Millennials or Generation $Y$, known as the generation with the largest number of population. Growing up in two major phenomenas, namely : technology and terrorism, millennials has already formed new characteristics. These characteristics ultimately affect the way they live and respond to an architectural object. On this day, millennials choose to live in big cities, even though the price of home ownership tends to be expensive. This triggers urbanization, to pursue a greater level of education. Jakarta as the capital of the country, is one of the cities with the largest population in Indonesia with expensive living costs. Every year, there are student urbanizations, who pursue education in Tarumanagara University. However, due to limited land avilability and population density, student housing has become inefficient. Both in terms of distance, time, and energy to reach the university while doing daily activities. For this reason, Tarumanagara University needs a dormitory with learning center for students.
\end{abstract}

Keywords: Dormitory; Housing; Millennial; Tarumanagara University

\section{PENDAHULUAN}

Generasi millennial sebagai generasi dengan jumlah terbesar yang saat ini menempati dunia seakan tidak pernah lepas dari perbincangan, termasuk dalam praktek arsitektural. Disebut juga sebagai Generasi $Y$ dan sebagian besar dianggap sebagai sekelompok orang yang lahir antara tahun 1980-2000 (Fourhooks, 2015).

Generasi millennial terbentuk di tengah dua fenomena besar, yakni teknologi dan terorisme telah membentuk sejumlah karakteristik baru. Karakteristik inilah yang akhirnya mempengaruhi respon millennial pada suatu objek arsitektur. Salah satunya, tingkat kepemilikan hunian yang menurun. Untuk millennial yang berusia 25 hingga 34 tahun, kepemilikan rumah ada di persentase 8 poin lebih rendah dari Baby Boomer pada usia itu dan 8,4 poin lebih rendah dari Generasi $X$ (Urban Institute, 2018). 


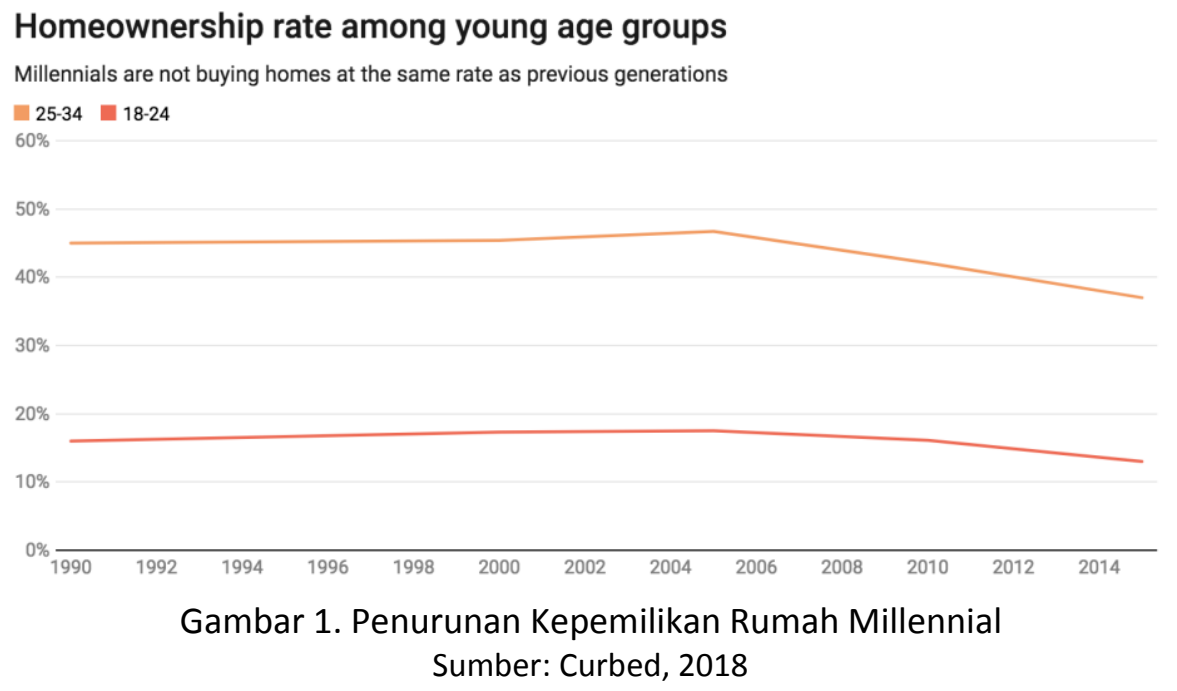

Millennial lebih memilih untuk tinggal di kota berbiaya tinggi dikarenakan tingkat pendidikan dan kemudahan yang didapatkan (Curbed, 2018). Jakarta sebagai ibukota negara Indonesia, saat ini terbilang memiliki biaya hidup tinggi dengan tingkat kependudukan yang tinggi. Hal ini memicu urbanisasi jutaan penduduk dari kota lain ke Jakarta untuk mengejar tingkat pendidikannya sebagai mahasiswa.

Tabel 1. Kepadatan Penduduk DKI Jakarta

\begin{tabular}{|c|c|c|c|c|c|}
\hline \multirow{2}{*}{\multicolumn{2}{|c|}{ Kabupaten/Kota }} & \multicolumn{3}{|c|}{ Jenis Kelamin (ribu) } & \multirow{2}{*}{$\begin{array}{l}\text { Rasio Jenis } \\
\text { Kelamin }\end{array}$} \\
\hline & & Laki-Laki & Perempuan & Jumlah & \\
\hline & 1 & 2 & 3 & 4 & 5 \\
\hline 1 & Kepulauan Seribu & 11720 & 11620 & 23340 & 100,86 \\
\hline 2 & Jakarta Selatan & 1096469 & 1089242 & 2185711 & 100,66 \\
\hline 3 & Jakarta Timur & 1436128 & 1407688 & 2843816 & 102,02 \\
\hline 4 & Jakarta Pusat & 457025 & 457157 & 914182 & 99,97 \\
\hline 5 & Jakarta Barat & 1246288 & 1217272 & 2463560 & 102,38 \\
\hline \multirow[t]{2}{*}{6} & Jakarta Utara & 867727 & 879588 & 1747315 & 98,65 \\
\hline & DKI Jakarta & 5115357 & 5062567 & 10177924 & 101,04 \\
\hline
\end{tabular}

Sumber: Badan Pusat Statistik

Keterbatasan lahan di kota Jakarta, menyebabkan jutaan mahasiswa kesulitan dalam menemukan hunian yang efisien. Efisiensi dapat dilihat dari segi jarak, waktu, maupun energi untuk mencapai universitas dan melakukan kegiatan sehari-hari. Oleh karena itu, dibutuhkan hunian yang efisien namun dapat mendukung mahasiswa dalam pembelajaran.

\section{KAJIAN LITERATUR}

\section{Generasi Millennial}

Pembangunan arsitektur di masa kini mulai memposisikan dan mengkhusukan diri untuk lingkungan baru yaitu generasi millennial. Millennial adalah nama lain dari generasi $Y$, yaitu generasi yang lahir di antara tahun 1981-1994. Generasi ini berada di antara generasi $X$ yang lahir di tahun 1965-1980 dan generasi Z yang lahir setelah tahun 1995. Dalam prakteknya kategori millennial memiliki tafsiran yang berbeda menurut beberapa ahli. Moser sendiri dalam Architecture 3.0 mengidentifikasi millennial sebagai generasi yang lahir di tahun 1980-2003 (Moser, 2013).

Howe \& Strauss mendefinisikan generasi sosial sebagai kumpulan dari semua orang yang lahir dalam kurun waktu kurang lebih dua puluh tahun atau sekitar satu fase kehidupan: masa kanak- 
kanak, dewasa muda, usia paruh baya, dan usia tua. Dengan jumlah populasi terbesar, tingkat pendidikan yang lebih tinggi, dan keberagaman etnis yang dimiliki, generasi millennial memiliki signifikansi yang besar dalam dunia (Howe \& Strauss, 2000).

Karakter pada tiap generasi dibentuk oleh fenomena lokal dan global di sekitarnya. Generasi millennial sendiri dibentuk oleh dua fenomena besar, yaitu: terorisme dan perkembangan teknologi (Fourhooks, 2015).

\section{a. Tech Savvy}

Generasi millennial tumbuh dan berkembang bersamaan dengan teknologi digital. Hampir seluruh generasi millennial (92\%) memiliki smartphone, dibandingkan dengan 85\% Gen X, 67\% Baby Boomers dan 30\% Silent Generation. Demikian pula, sebagian besar millennial (85\%) menggunakan media sosial (Pew Research Centre, 2018).

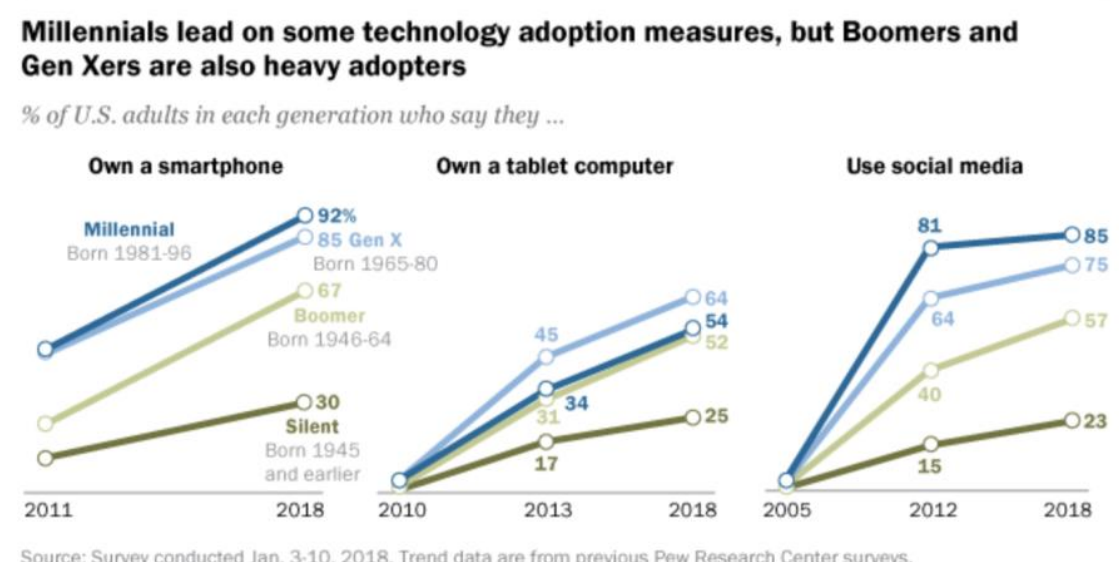

Gambar 2. Hubungan Generasi dengan Teknologi Sumber: Pew Research Centre, 2018

Kemudahan akses teknologi digital mendorong proses komunikasi terjadi real-time sehingga generasi ini tidak mengenal batas jarak atau borderless network, setiap orang dapat berhubungan langsung meski di negara berbeda. Simon Sinek mengatakan maraknya aplikasi berbasis online yang menawarkan kemudahan dalam kegiatan sehari-hari juga mendorong generasi millennial menjadi generasi yang serba instan (News.com.au, 2017).

b. Collaborative

Hidup di tengah keberagaman etnis, membuat millennial menjunjung tinggi nilai kerja sama (cooperate) dan kolaborasi (collaborate). Asumsi yang diterima secara luas tentang kata collaborate adalah millennial suka bekerja dalam tim (in team) untuk menyelesaikan sesuatu. Namun faktanya, millennial suka bekerja sebagai tim (on team) tetapi diakui secara individual. Bekerja dalam tim (in team) berarti individu bekerja atau berkontribusi sebagai bagian dari keseluruhan untuk mencapai tujuan bersama, dengan ketergantungan pada orang lain. Bekerja sebagai tim (on team) berarti menjadi bagian dari kelompok yang lebih besar untuk tujuan bersama, dengan tanggung jawab terpisah (Luttrell \& McGrath, 2016).

c. Value Oriented

Dibandingkan generasi lainnya, millennial berdedikasi untuk menjalani kehidupan yang penuh, dan tidak takut untuk mengambil keputusan berdasarkan hasrat. Mereka hanya menerima apapun yang cocok dengan prinsip dan apa yang ingin dilakukan dengan waktu dan kemampuannya. Sebuah survei terhadap 1.000 millennial di tiga kota Amerika tentang hubungan dengan pekerjaan menunjukkan bahwa millennial mementingkan nilai dan dampak pada dunia, dibandingkan memfasilitasi keluarganya secara finansial. Millennial memperjuangkan dampak positif, tujuan, semangat, kreativitas, dan kontribusi terhadap komunitas (Forbes, 2018a). 


\section{Pengertian Hunian}

Hunian adalah suatu cerminan dari diri pribadi manusia, baik secara perorangan maupun dalam suatu kesatuan dan kebersamaan dengan lingkungan alamnya dan dapat juga mencerminkan taraf hidup, kesejahteraan, kepribadian, dan peradaban manusia penghuninya, masyarakat ataupun suatu bangsa (Yudohusodo, 1991).

\section{Tipe Hunian}
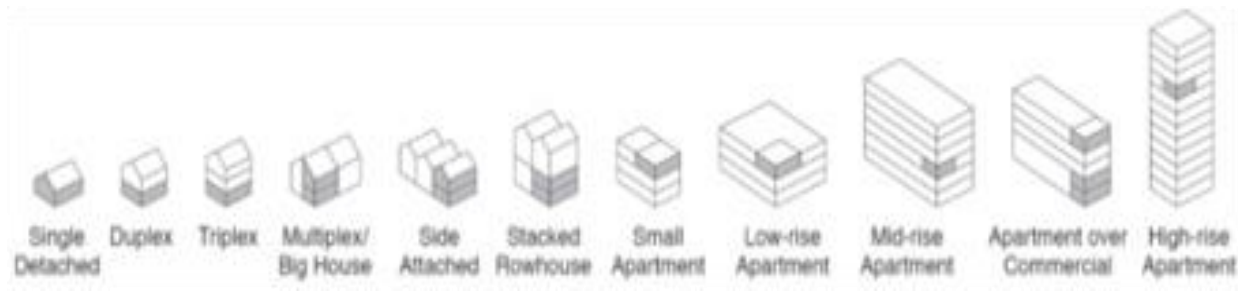

Gambar 3. Tipe Hunian

Sumber : slideshare.net

Keterbatasan lahan Jakarta membuat hunian sekarang beralih ke bangunan tipe susun. Bangunan dengan tipe susun pada umumnya memiliki 3 elemen yang membedakan :

a. Bentuk dari bangunan

- Slab: Bentuknya melebar memanjang, unit hunian disebar secara single-loaded atau doubleloaded.

- Tower: Memiliki bentuk yang lebih vertikal dengan core di tengah bangunan, terkadang memiliki podium di bawahnya.

- Courtyard: Menyediakan ruang komunal terbuka di tengah bangunan.

b. Akses terhadap bangunan

- Akses vertikal: Tingkat individualitas hunian yang tinggi, memiliki potensi untuk interaksi sosial antar penghuni dengan jumlah hunian sedikit yang bisa dikelola, bisa menciptakan banyak tipe unit.

- Akses horizontal: Koridor memanjang sering ditemukan di tipe block, orientasi unit hunian menghadap ke sisi yang di prioritaskan.

- Akses double-loaded: Hunian dapat diakses dari kedua sisi koridor, penggunaan ruang yang lebih efisien membuat kepadatan yang lebih tinggi.

- Akses individual: Akses langsung dari jalan, taman atau tangga pribadi, tidak memiliki ruang komunal, memiliki batas bangunan 2 atau 3 lantai.

c. Tipe unit hunian

- Single aspect: Hunian dengan 1 view, bagus untuk lahan dengan view yang kurang bagus

- Double aspect: Hunian dengan 2 view berbeda, terkadang terletak di tengah bangunan dengan akses double loaded atau horizontal.

- Corner aspect: Hunian dengan 3 view berbeda, sering ditemukan pada bangunan tower.

\section{METODE}

Menggunakan metode analisis dan sintesis dalam merancang desain bangunan, dari program sampai dengan studi - studi ruang baru yang sesuai dengan konsep efisiensi. Dalam metode penelitian menggunakan metode riset dengan menganalisa kebutuhan, permasalahan yang dihadapi dalam tapak terhadap penilitian apa yang akan dilakukan serta implementasinya dalam desain.

Dengan datang langsung ke lokasi untuk melihat keadaan di lapangan secara langsung, observasi dan mengumpulkan data-data yang berkaitan dengan fasilitas asrama dan fasilitas belajar dan juga keadaan lokasi, tidak hanya metode lapangan yang digunakan melainkan memanfaatkan sumber-sumber lain dari buku-buku, jurnal-jurnal yang bersangkutan dengan 
tema penilitian yang akan dikerjakan dimanfaatkan untuk tujuan mengambil informasi secara menyeluruh. Metode-metode yang digunakan bertujuan untuk menyempurnakan hasil survey yang diketahui sebelum mengerjakan tugas arsitektur yang akan dikerjakan.

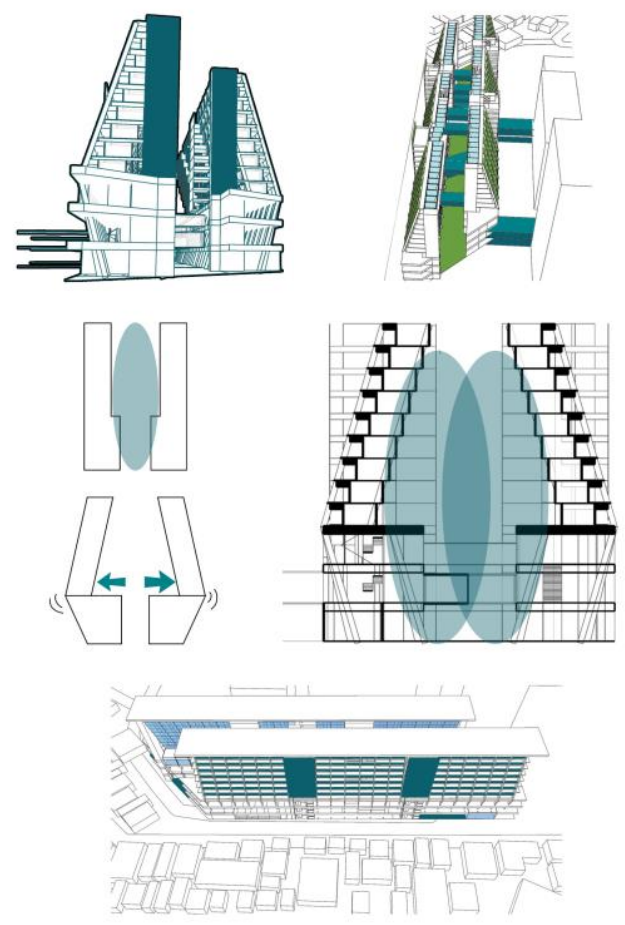

Gambar 4. Proses gubahan massa

Sumber : Dokumentasi Pribadi, 2019

\section{DISKUSI DAN HASIL}

Fasilitas Asrama dan Belajar Universitas Tarumanagara berlokasi di Jl. Letjen S. Parman No.1 RT.6/RW.6, Tomang, Grogol Petamburan, Jakarta Barat. Proyek ini terletak tepat di sebelah Kampus II Universitas Tarumanagara. Proyek ini memiliki luas tapak sebesar $15.400 \mathrm{~m} 2$. Dalam proyek ini fasilitas asrama sebagai program utama dan fasilitas belajar sebagai program pendukung asrama dan sebagai fasilitas pendukung kegiatan belajar mengajar yang terjadi di Universitas Tarumanagara.

Tabel 2. Data Tapak

\begin{tabular}{ccccccc}
\hline KDB & KLB & KB & KDH & KTB & TIPE & PSL \\
\hline 50 & 2,40 & 8 & 30 & 0 & T & P \\
\hline
\end{tabular}

$\begin{array}{llll}\text { Luas tapak } & : 15.400 \mathrm{~m}^{2} & \text { Unit hunian rusun } & : 486 \text { unit berukuran } 20 \mathrm{~m}^{2} \\ \text { KDB } & : 7.700 \mathrm{~m}^{2} & \text { Jumlah penghuni } & : 972 \text { orang } \\ \text { KLB } & : 36.960 \mathrm{~m}^{2} & & \end{array}$

Sumber: Penulis, 2019

Fasilitas Asrama ini dapat memfasilitasi mahasiswa-mahasiswa Universitas Tarumanaga pendatang yang membutuhkan tempat tinggal yang sesuai dengan cara hidup mereka. Fasilitas Asrama ini terbagi menjadi dua massa bangunan yang memisahkan massa untuk unit kamar mahasiswa laki-laki dan mahasiswa perempuan. Dengan masing-masing massa memiliki 243 unit 
kamar dengan kapasitas 2 mahasiswa per kamar nya. Satu massa bangunan ini dapat menampung 486 mahasiswa. Jadi fasilitas asrama ini dapat menampung 972 mahasiswa Tarumanagara.

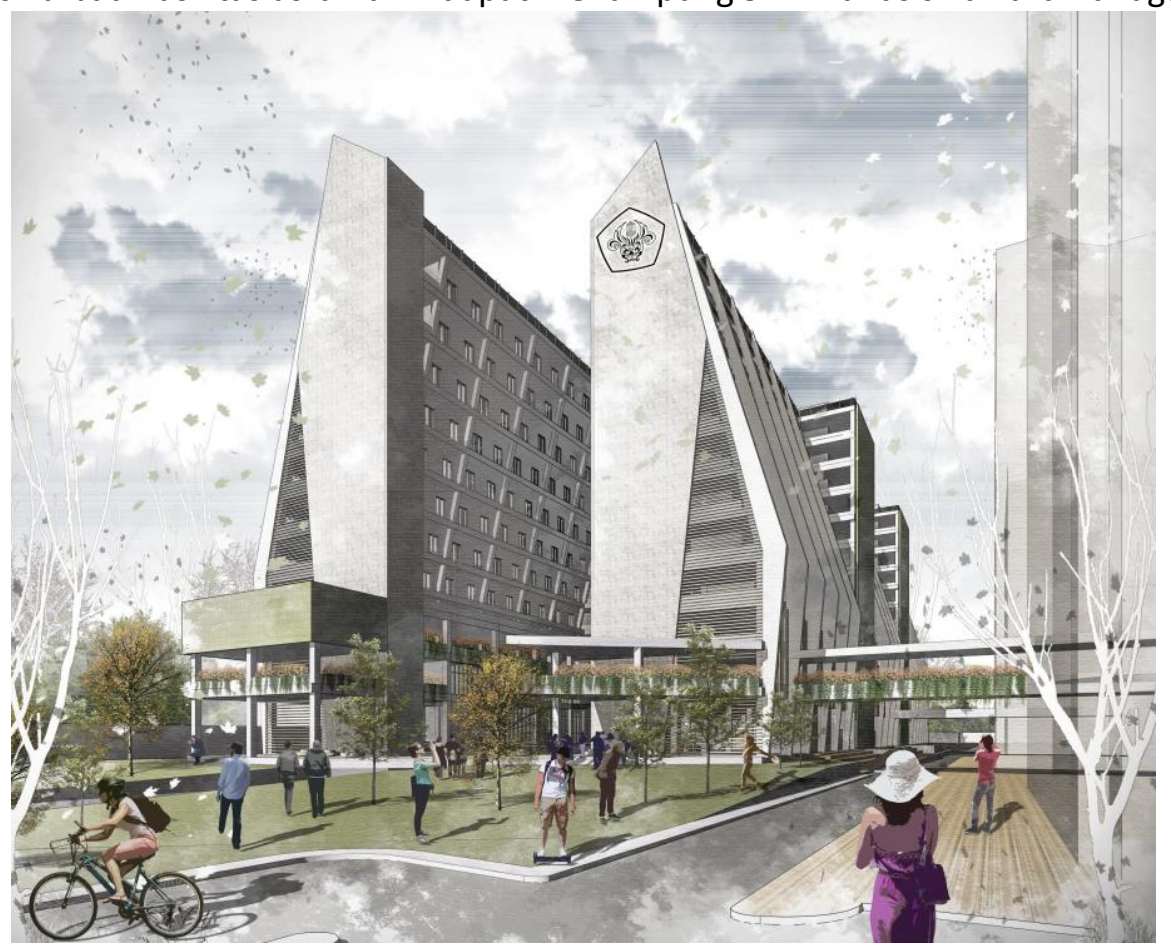

Gambar 5: Prespektif Eksterior

Sumber: Penulis, 2019

Dalam fasilitas asrama ini terdapat ruang-ruang bersama yang memiliki tujuan menyesuaikan cara hidup mahasiswa Universitas Tarumanagara. Adanya ruang-ruang bersama seperti ruang bersama, kamar mandi bersama, taman, kantin dan fasilitas belajar dapat menjadi sarana mereka untuk tetap terus berkolaborasi satu dengan yang lain nya membentuk sebuah lingkungan baru yang positif untuk proses belajar dan mengajar mahasiswa dan dosen Universitas Tarumanagara.

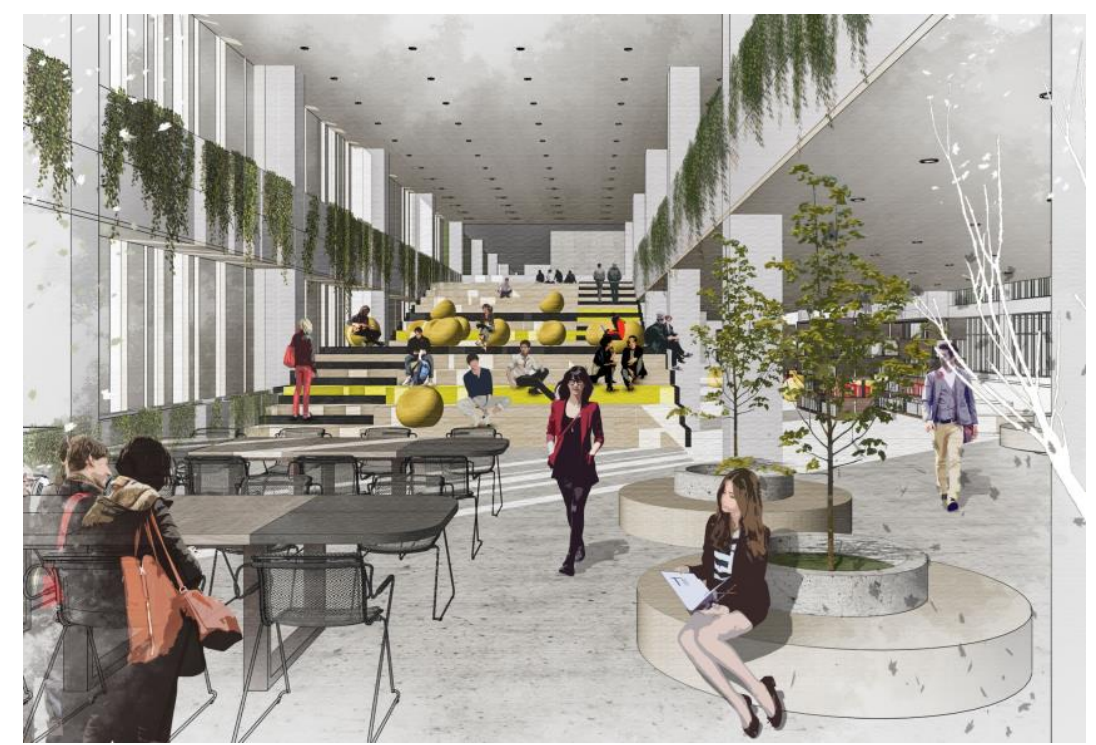

Gambar 6. Prespektif Fasilitas Belajar

Sumber: Penulis, 2019 


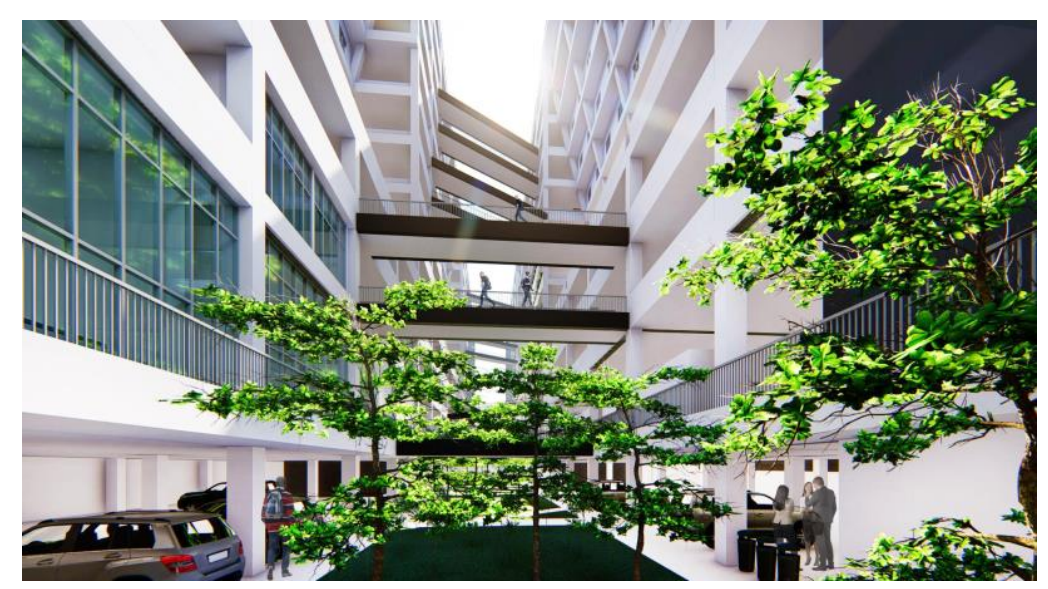

Gambar 7. Prespektif Antara Massa Bangunan Sumber: Penulis, 2019

Kedua massa ini disambungkan oleh beberapa jembatan yang langsung mengarah ke ruangruang komunal atau ruang-ruang bersama. Pada proyek ini jembatan adalah konektor utama pengguna fasilitas ini untuk bergerak bebas sesuai dengan keinginan nya. Dalam fasilitas belajar ini juga terdapat ruang seminar, ruang diskusi, ruang bersama (lounge), perpustakaan kecil, kantin, printshop, dan ruang audiovisual. Ruang-ruang ini diharapakan dapat membantu mahasiswa Universitas Tarumanagara untuk memaksimalkan potensi yang terdapat dalam diri mereka.

Bangunan ini terdiri dari 12 lantai. Lantai dasar merupakan area fasilitas umum pelayanan penghuni, lantai 2 dan 3 merupakan area fasilitas belajar dan latnai 4 sampai dengan lantai 12 merupakan fasilitas asrama.

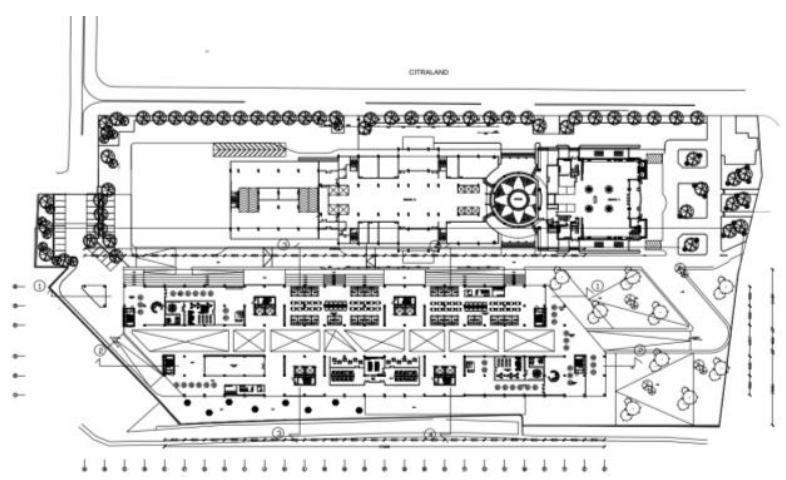

Gambar 8. Denah Lantai Dasar

Sumber: Penulis, 2019

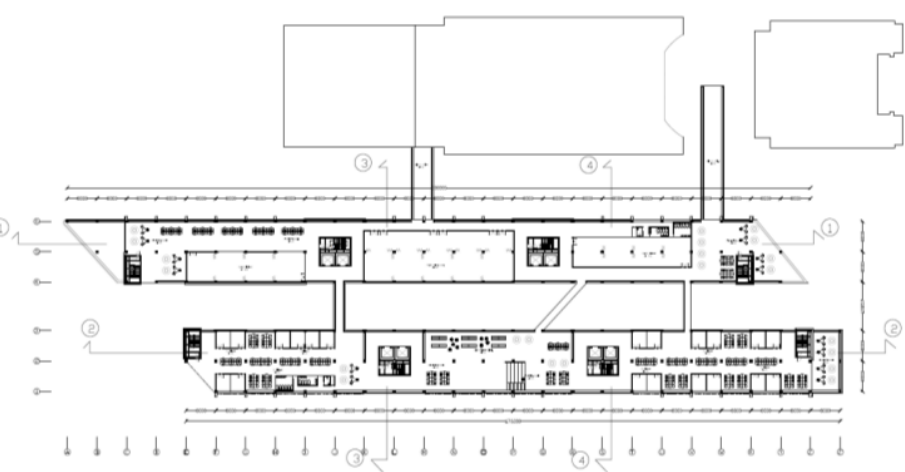

Gambar 9. Denah Fasilitas Belajar

Sumber: Penulis, 2019 


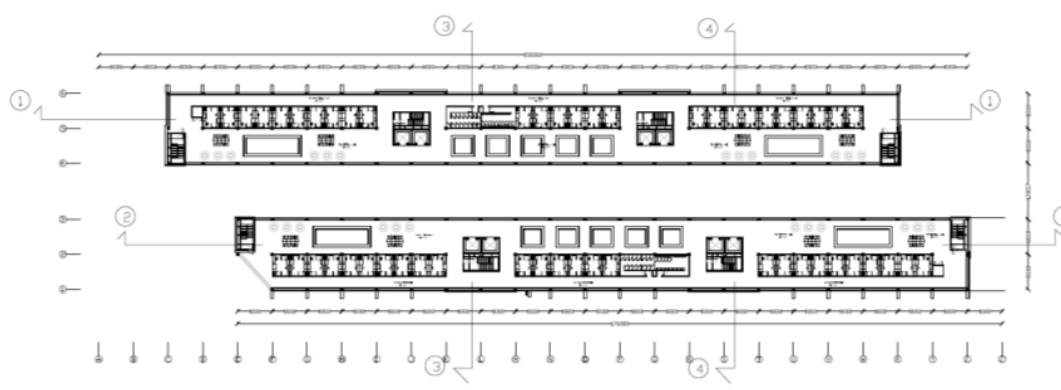

Gambar 10. Denah Fasilitas Asrama

Sumber: Penulis, 2019

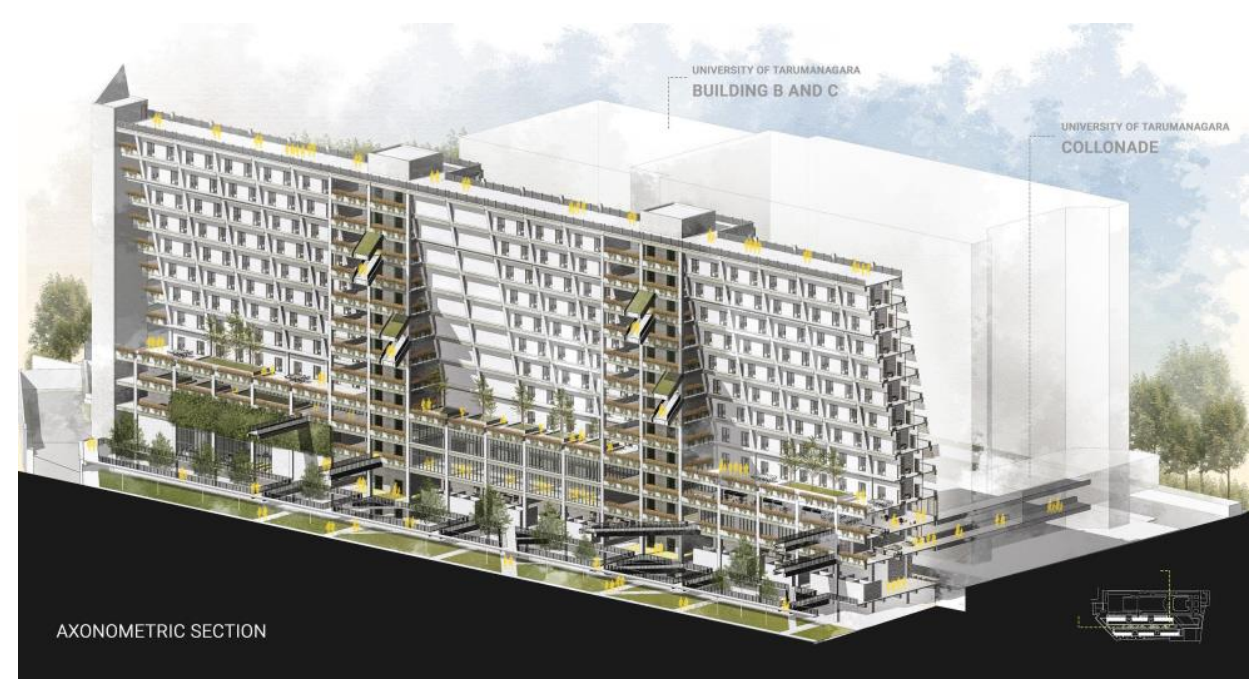

Gambar 11. Potongan Aksonometri

Sumber: Penulis, 2019

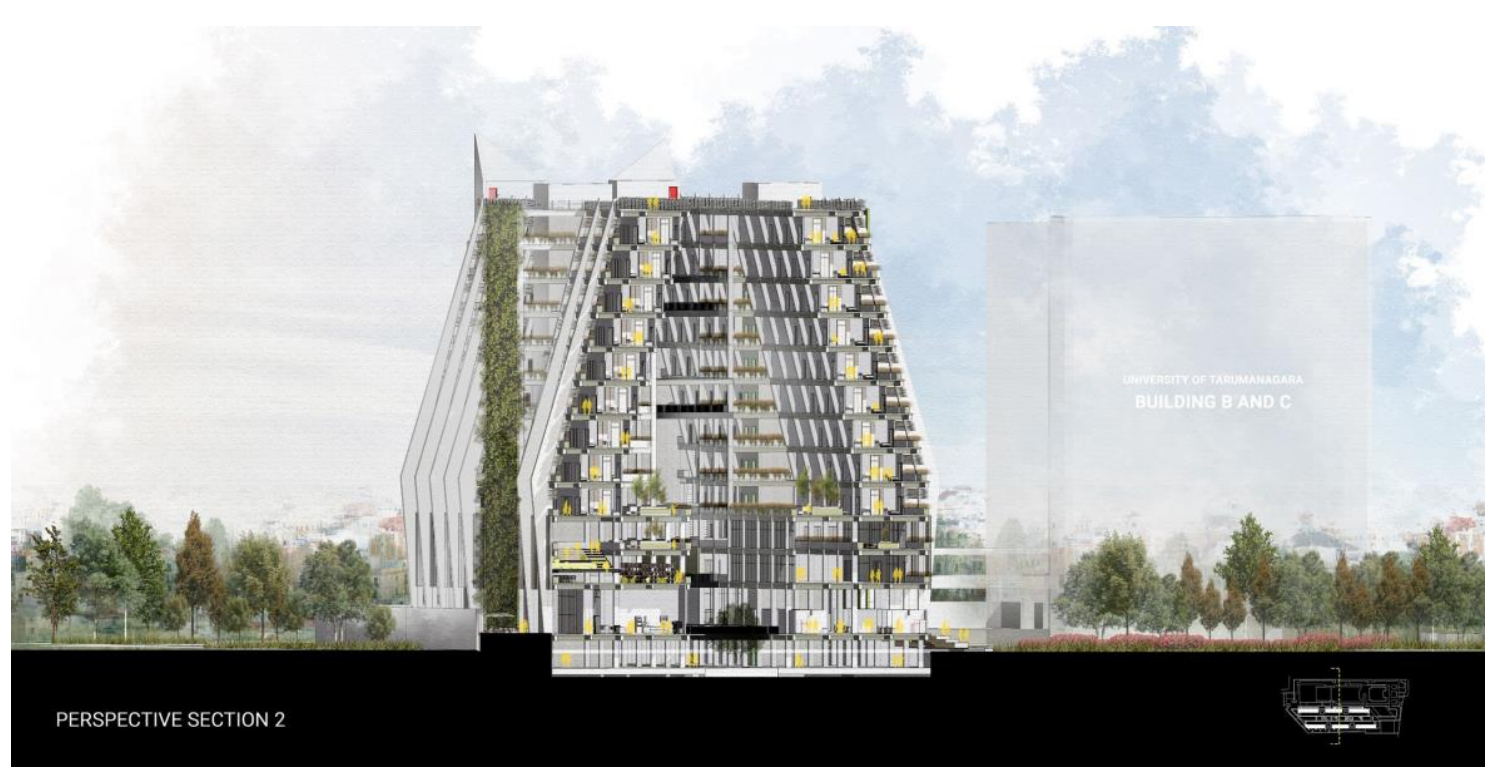

Gambar 12. Potongan Perspektif

Sumber: Penulis, 2019 


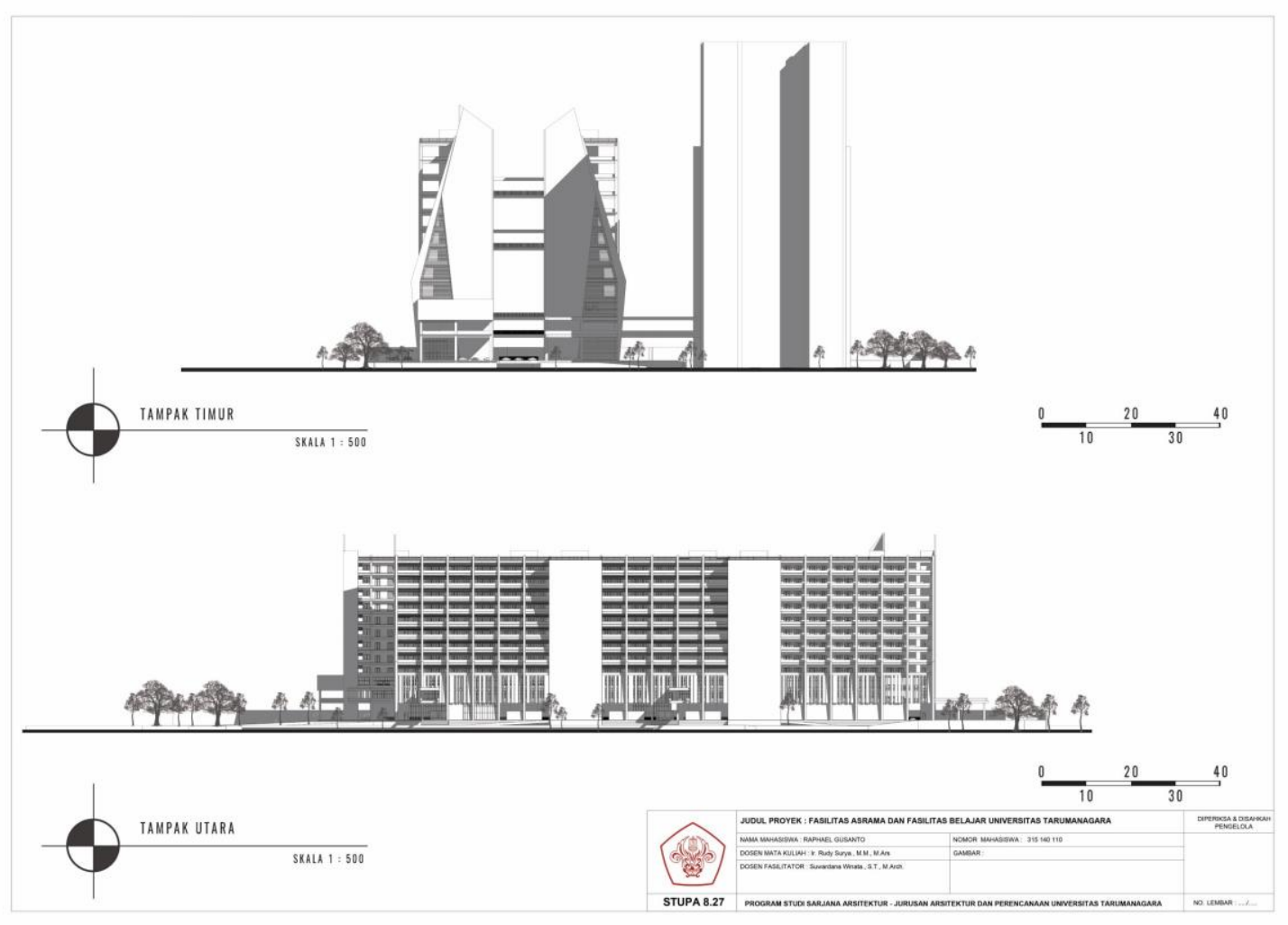

Gambar 13. Tampak Timur dan Utara

Sumber: Penulis, 2019

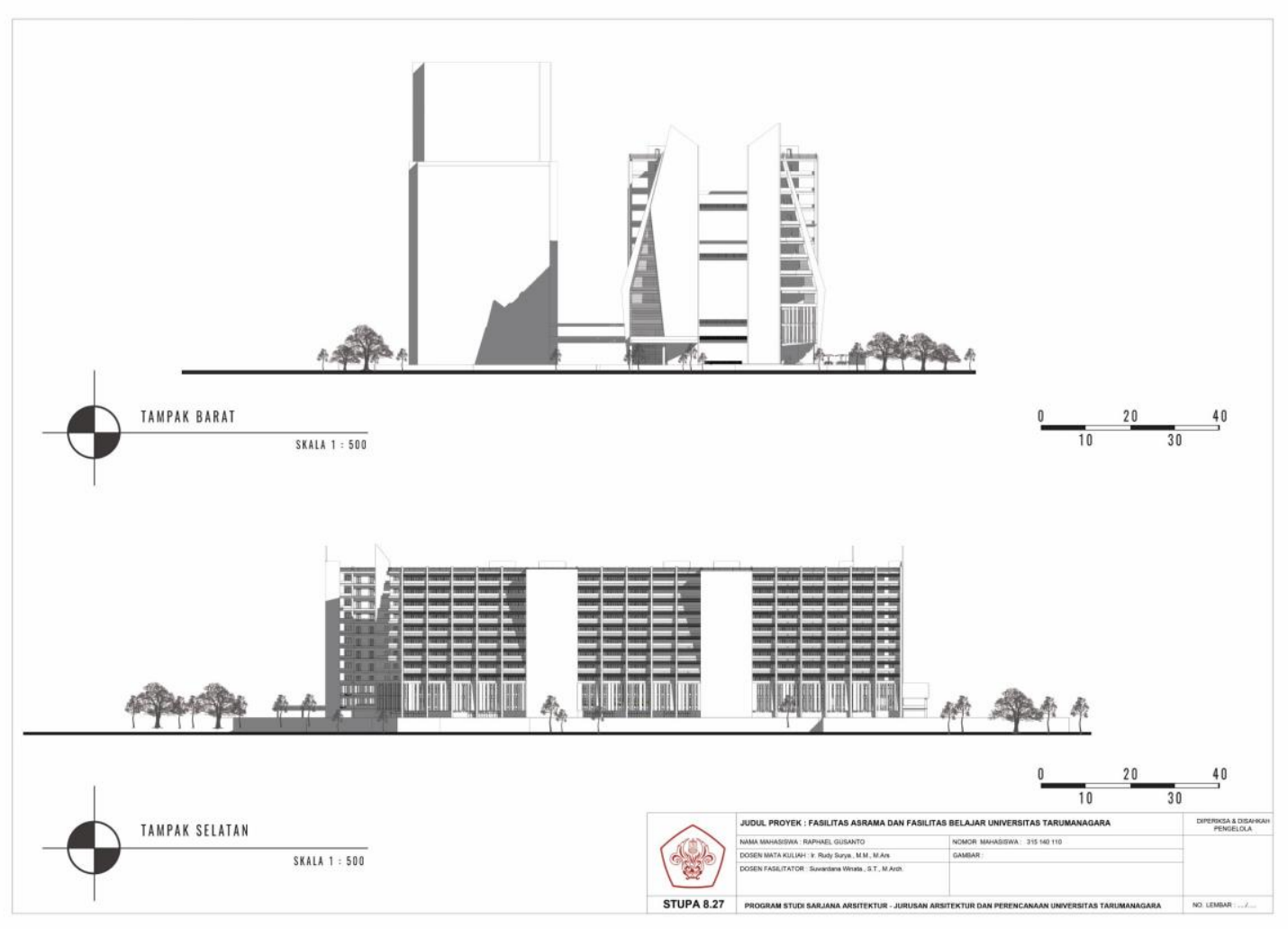

Gambar 14. Tampak Barat dan Selatan

Sumber: Penulis, 2019 


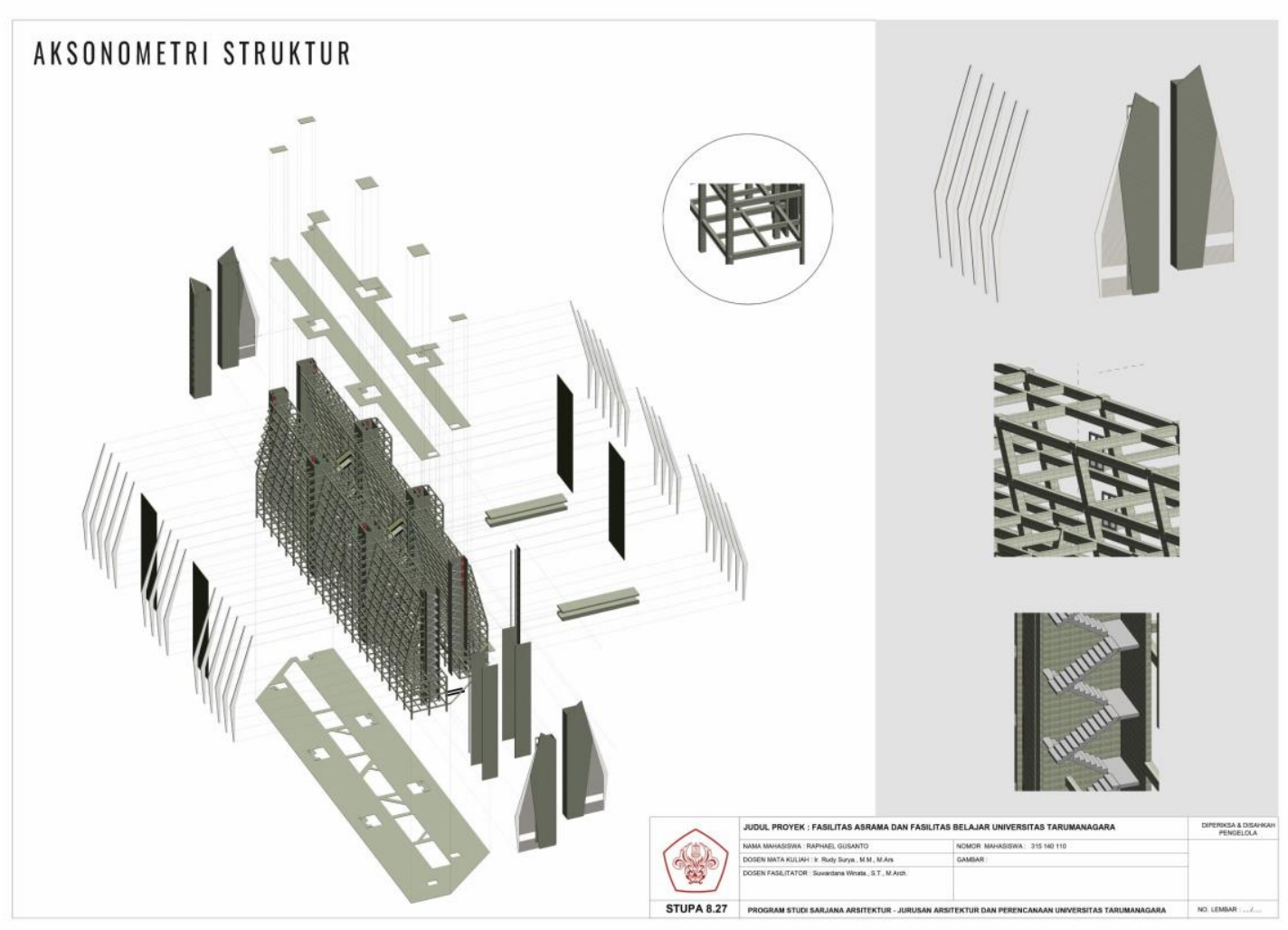

Gambar 15. Aksonometri Struktur

Sumber: Penulis, 2019

\section{KESIMPULAN DAN SARAN}

Kemajuan teknologi yang terjadi di generasi ini tidak bisa dipandang sebelah mata. Sebab tanpa kita sadari, kehadiranya secara perlahan dapat mengubah segala hal mendasar yang selama ini kita anggap sebagai hal yang biasa. Dengan memahami tentang karakteristik generasi millenial dan hubunganya dengan teknologi saat ini, kita akan dapat lebih mampu memahami kebutuhan, perilaku, serta karakteristik, dan dengan memfasilitasi sebuah hunian yang akan mampu mengoptimalkan interaksi dan kolaborasi antar generasi ini maupun antar generasi lainnya. Pembangunan proyek ini diharapkan dapat menjadi solusi dalam menjawab perkembangan zaman di era digital ini dengan mencipatakan sebuah fasilitas yang dapat menciptakan sebuah lingkungan hunian baru yang dapat memenuhi kebutuhan mahasiswa Universitas Tarumanagara agar mereka dapat memenuhi potensi yang ada di dalam diri mereka. Fasilitas Asrama dan Belajar Universitas Tarumanagara merupakan sebuah fasilitas untuk memenuhi kebutuhan mahasiswa Universitas Tarumanagara agar mereka memenuhi potensi mereka.

\section{REFERENSI}

Curbed. (2018). Why Aren't Millennials Buying Houses? Diperoleh 17 Februari 2019 dari https://www.curbed.com/2018/7/11/17541364/why-arent-millennials-buying-houses

Forbes. (2018). The Rise Of The Millennial, And Why They're Changing Work For The Better. Diperoleh darihttps://www.forbes.com/sites/forbescoachescouncil/2018/11/08/the-riseof-the-millennial-and-why-theyre-changing-work-for-the-better/\#ef252155e12e

Fourhooks. (2015). The Generation Guide - Millennials, Gen X, Y, Z and Baby Boomers. Diperoleh 16 Februari 2019, dari http://fourhooks.com/marketing/

Howe, N. \& Strauss, W. (2000). Millennials Rising: The Next Great Generation. New York, NY: Vintage 
Luttrell, R. \& McGrath, K. The Millennial Mindset: Unraveling Fact From Fiction. Lanham, MD: Rowman \& Littlefield

Moser, C. (2013). Architecture 3.0: The Disruptive Design Practice Handbook. London: Routledge

News.com.au. (2017). Four Main Reasons of Gen Y's Unhappiness. Diperoleh dari https://www.news.com.au/lifestyle/real-life/news-life/four-main-reasons-for-gen-ysunhappiness/news-story/360b4eff77c4f0e4d54a0ca65d73d72f

Pew Research Centre. (2018). Millennials Stand Out For Their Technology Use, But Older Generations Also Embrace Digital Life. Diperoleh 17 Februari 2019 dari http://www.pewresearch.org/fact-tank/2018/05/02/millennials-stand-out-for-theirtechnology-use-but-older-generations-also-embrace-digital-life/

Slide Share. Types of Housing and Residential Blocks. Diperoleh dari https://www.slideshare.net/sepalbarwary5/types-of-housing-and-residintial-blocks

Urban Institute. (2018). Millennial Homeownership. Diperoleh 17 Februari 2019 dari https://www.urban.org/research/publication/millennial-homeownership

Yudohusodo, S. (1991). Rumah Untuk Seluruh Rakyat. Jakarta: INKOPPOL 
